\title{
DUAL TRAINING SCHEMES PROMOTING ENTREPRENEURSHIP AND BUSINESS TRANSFERS - EXPERIENCES FROM LITHUANIA
}

\author{
Max Hogeforster ${ }^{1}$, Mira Alexander ${ }^{2}$ \\ Baltic Sea Academy, Blankeneser Landstrasse 7, 22587 Hamburg, Germany \\ E-mails: ${ }^{1}$ mhogeforster@baltic-sea-academy.eu (corresponding author); \\ 2malexander@baltic-sea-academy.eu
}

\begin{abstract}
While many political strategies focus on the promotion of start-ups, the existing companies are often neglected. Recent studies confirm, that more jobs are lost due to failed business transfers, then new ones are created. In fact, the generation change has reached the European SMEs and they suffer from a lack of successor to take over the business. Suitable successors are entrepreneurs and this article sets out to investigate a feasible way to educate and attract them to the SME sector. Based on solid literature research the paper argues, that a dual training, where students receive training in school and at the same time on the job can provide this needed expertise for entrepreneurship education. In 2016 such a dual training was initiated in Lithuania, this papers highlights results of the first comprehensive evaluation and provides an outlook on whether the graduates can become suitable successors in the long run.
\end{abstract}

Keywords: dual training, entrepreneurship, business transfer, SMEs, succession, Lithuania.

JEL Classification: M21, M53, I25.

\section{Introduction}

Across Europe, SMEs are in need of successors. While studies suggest that the European labour market is not only lacking skilled workers but also qualified company successors, the attention given to this topic by responsible authorities is rather limited (Calogirou, Fragozigis, \& Perrin-Boulonne, 2010). To take over a small or mediumsized company, the future manager needs to demonstrate a solid qualification and entrepreneurial spirit. However, entrepreneurial education is only in its beginnings. Furthermore, countries suffer from a school-based vocational training system, that fails to adequately qualify the workforce needed in the industries (Eichhorst, 2015). Therefore, this paper sets out to investigate a feasible way to educate and attract successors to the SME sector in Europe. Existing research indicates, that a dual education system, a work-based learning approach, can provide the demanded skills of entrepreneurs (cf. Jackson, 2015; Nabi, Liñán, Fayolle, Krueger, \& Walmsley, 2017; Nabi, Walmsley, Liñán, Akhtar, \& Neame, 2018; Williamson, Beadle, \& Charalambous, 2013). Hence, the article offers the proposition, that dual training can be an appropriate measure to educate future successors.
After a thorough review of the relevant literature in part two and three of the paper, the argument is further underlined with a review and analysis of a pilot action for a dual training program implemented in Vilnius, Lithuania. This pilot action demonstrates that indeed the cooperation between companies and schools, i.e. the training on the job, is a sustainable qualification and provides the labour force the companies need. While these findings underpin the results indicated from the literature review, they provide first-hand practical data on the issue that so far has not been available. Following this line of thought, the principle finding of the article is that the pilot dual training implemented is a suitable solution to qualify not only skilled workforce, but also future entrepreneurs that demonstrate sufficient potential to lead a company as a successor.

\section{SMEs' need for successors}

With exception of $0.2 \%$ all companies active in the non-financial business sector of the European Union are small and medium-sized enterprises (SMEs). They provide jobs for 93 Million people and account for $67 \%$ of the total employment. Around $93 \%$ of theses SMEs are micro companies with less than 10 employees (Oricchio, Lugaresi, Corvetto, \& Fontana, 2017; EU Commission, 
2017). These companies carry the European economy. Many of them are owner-managed and are at risk, once that owner retires. The European Commission estimates an approximate number of 450.000 firms in the EU being transferred to a new owner each year (European Commission, 2011).

Some numbers from Germany illustrate this impressively: about 135.000 companies must be transferred between 2014 and 2018, affecting approximately two million jobs (Hauser, Kay, \& Boerger, 2010). One third of these transfers, representing 600.000 jobs, are likely to fail due to a lack of awareness, knowledge, and regulatory frameworks (Calogirou et al., 2010). As a matter of fact every year more work positions are lost due to ineffective business transfers than new ones are created by start-ups (CECOP, 2013). While this is already an alarming figure, it becomes even more concerning considering that small and micro enterprises are the ones struggling most with such transfers (Best Boss Policy Paper, 2016). If this sector of the economy is not supported properly to carry out business transfers, the EU's main economic force is at stake.

Frequently it is stressed by policy makers how important it is to foster start-ups that creating more new companies will transform depressed economic regions, create innovation, and thus jobs. Undeniably most countries subsidize startups, and this can be helpful for the newly established firms, at least in the first few months (Caliendo, Hogenacker, Künn, \& Wießner ,2015). While that might be appealing to voters and an easy to understand idea to create companies and thus jobs, this approach is imperfect. The typical start-up is actually not innovative just because it is new, generates only a very limited number of jobs and generates little growth (Shane, 2009). It would be much more effective to concentrate at least a part of the efforts on keeping the existing firms running by promoting successful business transfers.

The situation in the Baltic Sea region is especially peculiar and several initiatives and projects aim to ease the situation. With the fall of the communist regimes, many took the chance to set up their own business. Now, thirty years later, many business owners are retiring (Varamäki, Tall, Viljamaa, \& Mäkelä, 2017). While most SMEs are family businesses, the rate of inheriting the business to a family member lies only between 15-35\% of all transfers (Centre for Strategy \& Evaluation Services, 2013) and traditionally most successors are rather sons than daughters (Martin,
2001). Even though it can be hoped that the number of daughters taking over companies will increase, family takeovers are the exception.

Hence, it becomes increasingly common to find a successor outside the family. Due to the general lack of skilled workers, finding a qualified successor is another obstacle to a successful business transfer. The demographic change, i.e. an ageing population, puts additional pressure on this and has been tackled only partly by active policy reforms, for example by reintegrating older workers (Kroon, Vliegenthart, \& van Selm, 2017). It becomes increasingly difficult to find a qualified workforce and successors, who are willing to take over and lead a small or medium-sized enterprise.

\section{Qualification of successors}

\subsection{Entrepreneurs}

To tackle the problem, the EU is focusing increasingly on raising awareness and setting up the framework conditions to facilitate business transfers, especially for SMEs (European Commission, 2013a). Regarding this, the Commission proposes to exchange best practices across Europe and raise the issue of special financial facilities, legal transformation, and a transparent market for business transfers (ibid.). However, even if awareness of the topic is raised and better framework conditions are created, the lack of qualified successors is still a decelerating factor in solving this problem. The lack of qualified successors is not a problem unique to business owners seeking to transfer their firm to a non-family member. Even if a business can be transferred to a family member, success of transition is not guaranteed, i.e. only one third of family businesses in the US survive the second generation, and tendencies in Europe are very similar (Sardeshmukh \& Corbett, 2011).

It is suggested by the literature that one of the main reasons for unsuccessful transfers, is the unwillingness to change. This is particularly true to businesses that stay in the family. A strong predecessor often intimidates the successor, limiting his or her propensity to take risks and take a different direction in steering the company. However, only the exploration of new growth opportunities as well as pro-activeness exemplified by the successor can lead to growth of business and hence the continuation of the firm (ibid.). It is thus imperative for a responsible business owner to look for an external successor in due time, who he can build up in the years leading up to his own retirement. Such a strategic planning of the succession 
process is often underestimated by company owners (Meijaard, Uhlaner, Flören, Diephuis, \& Sanders, 2005).

While this is already a strong indication of what a qualified or effective successor must be made of, other authors point to different directions. As outlined already thirty years ago (Churchill \& Hatten, 1987), another characteristic of an effective successor is the ability to increase revenues and profits in the company taken over. Indeed, the financial competence can be crucial, but it is not the only one. Otherwise bookkeepers would be the best successors, yet it rarely happens that a bookkeeper takes over a business. Certainly, the organization of the family business, its competitive environment, family relationships, and the succession planning process, are critical pieces of the succession puzzle (Goldberg, 1996). Additionally, the knowledge about the sector is important, but also not decisive, which is why even the most experienced senior employees do not automatically take over the company if their boss, the owner of the company, leaves. Returning to the skill of spotting and acting on opportunities which has been mentioned earlier, studies have shown that successors that could previously acquire competencies, such as problem-solving, negotiation, and communication skills, are usually more innovative and therefore, successful in their business take-over (Letonja \& Duh, 2015).

Furthermore, successors must show certain personal traits, e.g. locus of control or a risk-taking propensity, to positively affect business performance (Chrisman, Bauerschmidt, \& Hofer, 1998). In particular the level of self-confidence can make a difference in successfully taking over a company (Goldberg \& Woolrdige, 1993). These traits together with the proactivity when exploiting business opportunities, mean that in short, successors must be entrepreneurs; entrepreneurs who are familiar with the industry sector, educated in management and finances and experienced through enough practical training (Letonja \& Duh, 2015). As stated by Kellermanns and Eddleson (2006, p. 820): "In order for family firms to remain competitive, it is of the utmost importance to understand corporate entrepreneurship in family firms and how the family firm recognizes, pursues, and exploits entrepreneurial opportunities in an effort to grow and succeed".

As can already be seen, an entrepreneur needs to show several characteristics. However, there is no one-size-fits-all, clear-cut definition of what it means to be an entrepreneur. Many authors devote their time and effort researching entrepreneurial competencies. One of the most commonly known works are Lewis Goldberg's (1992) "Big Five". The five competencies making an entrepreneur are openness to experience, conscientiousness, extroversion, agreeableness, and neuroticism. However, it is crucial to note that it is not "the more, the better" for all five competencies. Similarly, Dr. Caird (2013) identified five key determinates of successful entrepreneurs, however, coming to a slightly different conclusion. Her top5 competencies of entrepreneurship include strive for achievement, strive for autonomy, creative tendencies, calculated risk-taking, and locus of control. Others, such as (Chrisman et al., 1998) have developed more comprehensive lists of entrepreneurial competencies. In order to enhance the level of entrepreneurship in the EU, the European Commission recently initiated the Entrepreneurship Competence Framework (Bacigalupo, Kampylis, Punie, \& Van den Brande, 2016).

This framework divides entrepreneurial competences into three main areas, further broken down to 15 competences. According to this framework, an entrepreneur needs to be able to spot opportunities, be creative, have a vision, value ideas, and think ethically and sustainably. Furthermore, he or she needs to have the following resources: self-awareness and self-efficacy, motivation and perseverance, financial and economic literacy, and the ability to mobilize others and further resources. Lastly, an entrepreneur needs to take the initiative, be strong at planning and managing, cope well with uncertainty, ambiguity and risk, work well with others, and learn through experience (McCallum, Weicht, McMullan, \& Price, 2018)

Build upon this list, several measures, projects, and tools have been developed with the aim of increasing the EU's entrepreneurial competencies and capacities. It seems to be one of the most predominate topics for European economy policy. Behind this, rests the underlying assumption that entrepreneurs are not born. Entrepreneurial skills change over time and they can be obtained through learning and training measures (Man, Lau, \& Chan, 2002). In particular in the last 20 years, entrepreneurship education has spread, and the actual impact is very different to what has been initially assumed (Nabi et al., 2017).

Recent studies indicate, that the relationship between entrepreneurship education and entrepreneurial intention is highly complex and the role of entrepreneurship education in developing entrepreneurial intentions in students is at least mixed 
(Nabi et al., 2018). While it also has been found that an increase in entrepreneurial training can be directly linked to a positive economic impact (Williamson et al., 2013), it becomes clear as well, that not every type of entrepreneurial education is the same.

In comparing different types of entrepreneurial education Jackson (2015) concluded that "students exposed to experiential learning processes and actively participating in campus enterprises acquired more business-related knowledge, skills and competences than those who simply confined their involvement to the completion of formal academic programs in such areas" (Jackson, 2015, p. 4). He continues in promoting a holistic crossdisciplinary approach that focuses on active engagement of students and staff with the local community and businesses to create stronger ties and more direct, on-the-job learning.

Hence, while there are many existing study courses teaching entrepreneurial studies in tertiary education, it is argued in this paper, that acquiring theoretical knowledge at higher education institutions is not sufficient to fully obtain and strengthen entrepreneurial competences. In order to counteract the lack of qualified successors a change in the education system is needed. Only when the interaction between students and businesses is given, it can be assured that the next generation of business successors, is adequately equipped with the right theoretical and practical skills to successfully take over businesses.

The possibility to encourage entrepreneurship education in early school years might be an option to influence the willingness of becoming an entrepreneur (Kroon, De Klerk, \& Dippenaar, 2003). Another, promising way to address this issue, is by looking at the German dual vocational education and training (VET) system, as it is built upon these exact premises. The dual system is the role model of work-based learning. Work-based learning always means to learn theory from school in conjunction with practice from the actual job (Huq \& Gilbert, 2013). In the German system, students spend time at vocational schools to acquire theoretical knowledge, and in businesses to get practical experience and expertise. Due to this setup, the interaction between students and businesses is guaranteed. Therefore, next generation successors, acquire the skills needed in the industry, and finish their education with theoretical and practical knowledge.

\subsection{Entrepreneurship through training in the dual system}

As has been mentioned a crucial step to addressing the lack of qualified successors, is a change in the education system. That way it is ensured that the next generation of businessmen and -women is equipped with the skills demanded by the labour market, in this case the SMEs. In particular the micro companies need a skilled workforce with actual practical experience. It is evident, that the work experience in the company is a crucial factor for a successful transition of ownership and that somebody with longer experience in the business, is more likely to succeed than an external (Goldberg, 1996). Since a trainee in the dual system will already be trained on the job in the company while, for example, studying management at school, this kind of work-based learning seems promising.

The benefits of the so-called dual VET are many-fold. For example, graduates of a dual VET are well prepared for the transition into the labour world, as the pedagogy of the training combine theory and working. Furthermore, is focused around problem-solving. Work-based learning enables contextual learning, i.e. the trainee is educated under real life conditions, learns how to work with others and what is feasible and what not (Rae, 2005). This leads to a relatively low youth unemployment rate in countries where dual VET is common like Austria, the Netherlands or Germany. In general, almost all graduates of the "dual system" of vocational education experience good chances to immediately access appropriate job positions (Konietzka, 2003). In fact, countries with traditional solid apprenticeship systems show a lower youth unemployment and a smoother transition to the labour market than those countries with a solely school-based vocational training (Jørgensen, 2015). Furthermore, due to the integration of companies into the education process, it is assured that students are learning skills according to the labour market's needs, hence providing qualified employees and, later on, successors. A work-based learning approach, like it is realized in the dual training system, can facilitate the transition from school to work while supplying employers with a skilled workforce at the same time (Eichhorst, 2015).

This is especially attractive for employers, as in many cases there is only a limited number of specialists on a certain topic available in the labour market. If companies engage in dual VET, they make sure to train new employees in their 
specialty fields, who could then act as potential successors. Additionally, due to the fact that students are not only studying at school but also learn directly in the companies, they often identify strongly with their training company and can get hired there easily after their VET. In conclusion, it is a win-win situation for both sides (cf. European Commission, 2016; Hogeforster \& Priedulena, 2015; Mühlemann \& Wolter, 2013).

Nevertheless, there is still a great deficiency of EU countries implementing work-based learning in their educational systems (European Commission, 2013b). Especially with regards to vocational training, many countries, also in the Baltic Sea Region, adhere to their school-based vocational systems. However, particularly entrepreneurship education benefits from the dual system (Jackson, 2015). For companies the dual training system is highly relevant since they get the employee they need, educated under real life conditions at their company and familiar to their customers.

One of the biggest challenges of a dual training system is to get enough companies on board that are willing and capable of qualifying trainees on the spot, in particular since in most countries these companies pay the school tuition fee and also a small salary. Before the shortage of a skilled workforce, many companies preferred to hire a graduate from a dual training course instead of investing a couple of years to educate their own workforce. This changed due to the lack of skilled labour and more companies are willing to invest early, followed by making good job offers after graduation, in order not to lose the now perfectly qualified employee to a competitor.

Also, companies discovered, that early investment in a trainee pays off. Unlike externals that join the company, the trainee is beneficial from day one of his work contract and does not need to familiarize himself with machines, customers or colleagues.

\section{Dual Training pilot in Lithuania}

Like any other European country, Lithuania, too, is looking how to increase the attractiveness of its VET sector and educate more entrepreneurs to start or take over companies and thus easy the generation shift. Since 2007 Lithuania was very active to improve to vocational training sector. Like many European Union member states, Lithuania suffered from a high unemployment rate of young academics (Repečkienè, Kvedaraitè, Žvirelienè, \& Glinskienè, 2012), but at the same time showed a lack of skilled workers (Hogeforster, 2014). Apprenticeship-type training did exist but was not very strong in recent decades (CEDEFOP, 2013). Political initiatives of the government to move the rather supply work-based model of VET to a more demand-led VET by increasing the flexibility and responsiveness of vocational training became evident in the last years (Kliminskas \& Pagiriene, 2015). Within an Erasmus + project, a work-based learning program has recently been introduced to the Lithuanian VET system. Institutions from five countries teamed up in 2014 and developed curricula for dual training in Hungary, Lithuania and Poland. Lithuania was the first to successfully finalize such curricula and implement the training. The training curricula was developed by the Panevėžys College. The program was carried out together with companies from September 2015 until June 2017 at the Vilniaus Statybininkų Rengimo Centras (Vilnius Builders Training Centre).

For the test-run, the procession of a Finisher (Builder) was chosen. It is set on Level 3 of the European qualification framework $(\mathrm{EQF})$ which corresponds to Level 3 of the Lithuanian qualifications level (LTQF). In fact, the LTQF created an important structure for new education forms (Laužackas \& Tūtlys, 2007). The training awards 120 ECTS, earned in 2400 hours. Of course a shift from a school-based training to a training in the company, asks for qualification of the supervisor in that company on the spot. It is necessary to have specially prepared and qualified trainers among the staff of the enterprises, possessing both highly developed practical skills and pedagogical competences permitting to train the apprentices (Kliminskas \& Pagiriene, 2015). Thus a train-thetrainer scheme of 80 hours has been created as part of the before mentioned project. Additionally, the school trainers provided some advice regarding pedagogical aspects of training and shared their teaching experiences with the company staff.

The school based vocational training of 720 hours was very successful. With $95.2 \%$ the attendance rate was very high. Also the average mark for theory for the whole group was 8.7, which is a solid result (Černeckienè, 2017). In Lithuania the lowest positive mark is 4 and the highest is 10 .

The practical training consisted of 1680 hours, i.e. $70 \%$ of the total training time. Initially it was not easy to attract companies to become a training institution, but the interest and self-understanding of companies to also offer training positions in a dual system seems to grow. While it is a common understanding in countries like Austria 
or Germany that the companies pay the trainee from day one, this is not yet always the case in other regions. Nevertheless, in case of this dual training wages were paid to all trainees from the Lithuanian companies from the $2^{\text {nd }}$ semester on. The practical training in the companies has been based on real work situations at different construction sites in Vilnius. For three training semesters, the trainees worked in the company three days a week. In the last semester, during their apprenticeship, they were in the companies every day. Since this curriculum was one of the first real dual trainings in Lithuania and the corresponding law has only been changed at the end of 2017, the trainings were not formalized and only considered a non-formal training. On-site training are often considered non-formal or informal learning anyway (Lee et al., 2004) and there is simply no need for formalisation at all. Other than only learning at a school, this informal learning corresponds to the needs and expectations of the real world (Tavistock Institute of Human Relations, 2002) and is thus very powerful and valuable for the employer (Marsick \& Volpe, 1999).

The curriculum of the practical training was prepared and coordinated by the employer and a teacher. The vocational training experience (training content, learners' attendance, assessment of learning outcomes and other information) were recorded in diaries. The average mark for the practice part for the whole group was 9.4 out of 10 , and the attendance rate was $97.1 \%$ for the whole group for the 1st year of training (Černeckiene, 2017). Regarding the final exams in June 2017, the results were likewise positive, with 8.62 for the theoretical part and an average assessment for practical performance of 9.33 .

Corresponding to the requirements of formal vocational education training (approved by the Minister of Education and Science of the Republic of Lithuania order No. V-482, dated 15-03-2012, revised version No. V-479, dated 08-05-2015), a modular apprenticeship program was developed. The training consists of an introductory module, 11 modules for professional competence and 3 modules regarding the final apprenticeship. One module awards less than 10 credits. All Finisher dual training program modules, with exception of the apprenticeship, consist of practical and theoretical training hours.

Introductory builder's module.

Compulsory modules:

1. Construction drawing.

2. General construction works.

3. Basics of masonry and concrete laying.
4. Manual wood processing.

5. Thermal insulation of buildings.

6. Plastering.

7. Tiling.

8. Painting.

9. Covering gluing.

10.Fixing plasterboard panels.

11. Fixing decorative panels and linear elements.

Final modules. Apprenticeship.

The introductory module is designed to familiarize the students with professional activity in the field of vocational training and the economic sector. The following compulsory modules for professional qualification include training content for the students' preparation for activities specific to the qualification they aim to gain. However, there is enough flexibility to adjust the training according to the needs of the individual student as well as the labour market. Lastly, the final modules are for summarizing the theoretical knowledge, consolidation of practical skills and preparation for the assessment of competences. The content of the modules is composed in a way that imparts all competences of a finisher defined as the standard according to Lithuanian regulations, including the ability of learners to plan, implement and control their activities.

These outcomes clearly indicate, that the dual training approach was very successful. One of the biggest successes is demonstrated in other numbers: $16.5 \%$ of the trainees went to work for other companies, $21 \%$ decided to continue VET training and actually $8.5 \%$ went to university, but the majority of all trainees, indeed $50 \%$ stayed to work for their training company after graduation. In particular this last number is very relevant. Many companies offering dual training positions fear that the trainee, they invested in for a number of years, will actually leave the company after graduation. But the numbers of this pilot training demonstrate, that this applies to only every second trainee.

The other half received a solid training and is perfectly familiar with the company's business and - other than external applicants - will be of high value from day one of his work after graduation. The graduate of this work-based learning model is not only well educated from the vocational school, but already familiar with processes, know-how, customers etc. The final report further highlights that there has been constant collaboration between the school and the company in order to ensure best correlation in theoretical and practical training (Černeckienè, 
2017), which is an important additional value of such a work-based learning model.

The created training program can be considered a success and a role-model for Lithuania and other countries. Few months after the first training ended, in December 2017, the parliament of Lithuania consented to the draft recast of vocational education and training law. This draft, Lietuvos Respublikos profesinio mokymo istatymo Nr. VIII-450, stresses the significance of apprenticeship and work-based learning. It aims to facilitate the acquisition of practical experience for students not only through the use of the infrastructure of vocational training institutions, but indeed in the real workplace.

\section{Limitations and further research}

The novelty of the education course and the newly passed law that only dates back a few months ago limits ability of the research to make reliable claims on the long-term effects and outcomes of the dual vocational training. It will take some time for the young graduate to evolve from a valuable worker in the company they have been trained in to, to take over the company. The same holds for the numbers presented in the analysis.

While they represent well how the pilot action has been perceived, they cannot be used to predict future trends, as the amount of data is simply too little. Nevertheless, the change of law shows great political commitment towards the issue, leading to the justified expectation that the number of dual trainings, structured similarly according to the principles of work-based learning, will show a solid increase in the near future. Furthermore, even though a solid foundation has been laid by the dual training, transfer processes in a company, indicating a generational change, usually take two to five years.

Hence, future research needs to address two main issues. First, new cohorts of the presented dual VET as well as new dual VETs for other occupations need to be reviewed and analysed to enrich the preliminary findings of this paper or limit and revise the proposed hypothesis. Second, research needs to be dedicated towards the graduates of these trainings and their career paths to establish whether alumni of dual trainings indeed become successors.

Moreover, the data presented in this case is limited to Lithuania. While some aspects can be easily transferred to other countries, others cannot. Especially, with regards to education systems and business culture, it is crucial to adapt measures to national and regional characteristics. Therefore, if similar measures are implemented in other countries of the BSR a comparative study would be beneficial to be able to come to more generalizable conclusions.

\section{Conclusions}

New entrepreneurs are urgently needed to take over the high number of retiring SME owners in Europe. Existing literature demonstrates, that dual training programs are an effective method to educate future entrepreneurs on the job and can be rated as an interesting education alternative for young people. Such qualified entrepreneurs, that have not only been educated but in fact worked for years in the company, having obtained the concrete, sector-relevant knowledge, can be build up as suitable successors. The successful implementation of a dual training program in Lithuania underlines these assumption and experiences. It demonstrates that there is a need for trainings like this and companies willing to train young people on the job. The high number of trainees staying in the company after the training is completed shows that it is an interesting recruitment tool for a qualified workforce too. The described pilot action indicates that there is not only a high interest from potential trainees, but also from companies that are willing to train on the job. Follow up research in a couple of years needs to evaluate, if dual trainings are also a valid instrument to recruit future managers, thus successors.

\section{References}

Bacigalupo, M., Kampylis, P., Punie, Y., \& Van den Brande, G. (2016). EntreComp: The Entrepreneurship Competence Framework. Luxembourg: Publication Office of the European Union; EUR 27939 EN.

Best Boss Policy Paper. (2016). Best Boss Erasmus + Project Consortium. Retrieved from http://www.fhmittelstand.de/fileadmin/Forschung/Policy_Paper_Best_ Boss onlineversion_01.pdf

Caird, S. (2013). General measure of enterprising tendency test, GET. Retrieved from http://www.get2test.net/ get2test.html

Caliendo, M., Hogenacker, J., Künn, S., \& Wießner, F. (2015). Subsidized start-ups out of unemployment: a comparison to regular business start-ups. Small Business Economics, 45(1), 165-190. https://doi.org/10.1007/s11187-015-9646-0

Calogirou, C., Fragozigis, K., \& Perrin-Boulonne, H. (2010). Business dynamics: start-ups, business transfers and bankruptcy. Brussels: European Commission, Entrepreneurship Unit, DG Enterprise and Industry.

CECOP - The European Confederation of Cooperatives and worker-owned enterprises active in industries and services. (2013). Business Transfers to Employees under 
the Form of a Cooperative in Europe - Opportunities and Challenges. Brussels: The European Confederation of Cooperatives and worker-owned enterprises active in industries and services. Retrieved from http://www.cecop.coop/IMG/pdf/bussiness_transfers_ to_employees_under_the_form_of_a_cooperative in_europe_cecop-4.pdf

CEDEFOP. (2013). Vocational education and training in Lithuania. Shot description. Luxembourg: Publications Office of the European Union. Retrieved from http://www.cedefop.europa.eu/files/4128_en.pdf

Centre for Strategy \& Evaluation Services. (2013). Evaluation of the implementation of the 2006 Commission Communication on Business Transfers. Kent: Centre for Strategy \& Evaluation Services.

Chrisman, J., Bauerschmidt, A., \& Hofer, C. (1998). The determinants of new venture performance: An extended model. Entrepreneurship Theory and Practice, 23(1), 5-29. https://doi.org/10.1177/104225879802300101

Churchill, N. C., \& Hatten, K. J. (1987). Non-market-based transfers of wealth and power: A research framework for family businesses. American Journal of Small Business, 11(3), 51-64.

https://doi.org/10.1177/104225878701100305

Černeckiene, R. (2017). Report on the implementation of the work based learning concept in Lithuania. Retrieved from http://www.work-based-learning.eu/project-results/

Eichhorst, W. (2015). Does vocational training help young people find a (good) job?. IZA World of Labor.

European Commission. (2011). COM/2011/0078 final. Review of the "Small Business Act" for Europe.

European Commission. (2013a). Entrepreneurship 2020 Action Plan - Reigniting the entrepreneurial spirit in Europe. Brussels: European Commission.

European Commission. (2013b). Work-based learning in Europe - Practices and policy pointers. Brussels: European Commission, DG Education and Training.

European Commission. (2016). A new skills agenda for Europe - Working together to strengthen human capital, employability and competitiveness. Brussels: European Commission.

European Commission. (2017). Annual report on European SMEs 2016/2017 Brussels: European Commission, DG Internal Market, Industry, Entrepreneurship and SMEs.

Goldberg, L. R. (1992). The development of markers for the big-five factor structure. Psychological Assessment, 4(1), 26-42. https://doi.org/10.1037/1040-3590.4.1.26

Goldberg, S. D. (1996). Research note: Effective successors in family-owned businesses: Significant elements. Family Business Review, 9(2), 185-197. Retrieved from http://citeseerx.ist.psu.edu/viewdoc/download? doi $=10.1 .1 .892 .3033 \&$ rep $=$ rep $1 \&$ type $=$ pdf

Goldberg, S. D., \& Wooldridge, B. (1993). Self-Confidence and managerial autonomy: Successor characteristics critical to succession in family firms. Family Business Review, 6(1), 55-73. https://doi.org/10.1111/j.1741-6248.1993.00055.x

Hauser, H. E., Kay, R., \& Boerger, S. (2010). Unternehmensnachfolgen in Deutschland 2010 bis 2014: Schätzung mit weiterentwickeltem Verfahren (No. 198). IfM-Materialien, Institut für Mittelstandsforschung (IfM) Bonn. Retrieved from https://www.econstor.eu/ bitstream/10419/51541/1/660747057.pdf

Hogeforster, M. (2014). Future challenges for innovations in SMEs in the Baltic Sea Region. Procedia-Social and
Behavioral Sciences, 110(2014, January), 241-250. https://doi.org/10.1016/j.sbspro.2013.12.867

Hogeforster, M., \& Priedulena, E. (2015). Manual for trainings and dual study courses of the sector skills alliance "Skills Energy BSR". Books on Demand.

Huq, A., \& Gilbert, D. H. (2013). Enhancing graduate employability through work-based learning in social entrepreneurship: A case study. Education+Training, 55(6), 550-572.

https://doi.org/10.1108/ET-04-2012-0047

Jackson, T. (2015). Entrepreneurship training in tertiary education: Its development and transfer. Local Economy, 30(5), 484-502.

https://doi.org/10.1177/0269094215589143

Jørgensen, C. H. (2015). Challenges for work-based learning in vocational education and training in the Nordic countries. In Working and learning in times of uncertainty (pp. 159-171). SensePublishers, Rotterdam. https://doi.org/10.1007/978-94-6300-244-8_12

Kellermanns, F., \& Eddleston, K. (2006). Corporate entrepreneurship in family firms: A family perspective. Entrepreneurship Theory and Practice, 30(6), 809-830. https://doi.org/10.1111/j.1540-6520.2006.00153.x

Kliminskas, R., \& Pagiriene, R. (2015). The concept of the implementation of dual vocational training in Lithuania (Vol. 21, pp. 37-55). Work-based learning around the Mare Balticum. Baltic Sea Academy Series.

Konietzka, D. (2003). Vocational training and the transition to the first job in Germany - new risks at labor market entry?. In The sociology of job training (pp. 161-195). Emerald Group Publishing Limited. https://doi.org/10.1016/S0277-2833(03)12007-9

Kroon, A. C., Vliegenthart, R., \& van Selm, M. (2017). Between accommodating and activating: Framing policy reforms in response to workforce aging across Europe. The International Journal of Press/Politics, 22(3), 333356. https://doi.org/10.1177/1940161217708525

Kroon, J., De Klerk, S., \& Dippenaar, A. (2003). Developing the next generation of potential entrepreneurs: co-operation between schools and bussinesses?. South African Journal of Education, 23(4), 319-322.

Laužackas, R., \& Tūtlys, V. (2007). Modelling the national qualifications framework of Lithuania into the European qualifications framework. European Journal of Vocational Training, 43(3), 42.

Lee, T., Fuller, A., Ashton, D., Butler, P., Felstead, A., Unwin, L., \& Walters, S. (2004). Learning as work: Teaching and learning processes in the contemporary work organisation. Learning as work research paper, (2), p. 41. https://doi.org/10.1596/1813-9450-3370

Letonja, M., \& Duh, M. (2015). Successors' innovativeness as a crucial succession challenge of family businesses in transition economies: The case of Slovenia. In L. Dana. \& V. Ramadani (Eds.), Family businesses in transition economies: Management, succession and internationalization. Springer International Publishing Switzerland.

Man, T. W., Lau, T., \& Chan, K. F. (2002). The competitiveness of small and medium enterprises: A conceptualization with focus on entrepreneurial competencies. Journal of Business Venturing, 17(2), 123-142. https://doi.org/10.1016/S0883-9026(00)00058-6

Marsick, V. J., \& Volpe, M. (1999). The nature and need for informal learning. Advances in Developing Human Resources, 1(3), 1-9.

https://doi.org/10.1177/152342239900100302 


\section{DUAL TRAINING SCHEMES PROMOTING ENTREPRENEURSHIP AND BUSINESS TRANSFERS - EXPERIENCES FROM LITHUANIA}

Martin, L. (2001). More jobs for the boys? Succession planning in SMEs. Women in Management Review, 16(5), 222-231. https://doi.org/10.1108/EUM0000000005584

McCallum, E., Weicht, R., McMullan, L., \& Price, A. (2018). EntreComp into action: get inspired, make it happen. M. Bacigalupo \& W. O'Keeffe (Eds.). Luxembourg: Publication Office of the European Union, EUR 29105 EN

Meijaard, J., Uhlaner, L., Flören, R., Diephuis, B., \& Sanders, B. (2005). The relationship between successor and planning characteristics and the success of business transfer in Dutch SMEs. EIM Business \& Policy Research. Zoetermeer.

Mühlemann, S., \& Wolter, S. (2013). Return on investment of apprenticeship systems for enterprises: Evidence from cost-benefit analyses. Analytical Report No. 16. European Expert Network on Economics of Education.

Nabi, G., Liñán, F., Fayolle, A., Krueger, N., \& Walmsley, A. (2017). The impact of entrepreneurship education in higher education: A systematic review and research agenda. Academy of Management Learning \& Education, 16(2), 277-299. https://doi.org/10.5465/amle.2015.0026

Nabi, G., Walmsley, A., Liñán, F., Akhtar, I., \& Neame, C. (2018). Does entrepreneurship education in the first year of higher education develop entrepreneurial intentions? The role of learning and inspiration. Studies in Higher Education, 43(3), 452-467. https://doi.org/10.1080/03075079.2016.1177716

Oricchio, G., Lugaresi, S., Corvetto, A., \& Fontana, S. (2017). SMEs in Europe: An overview. In SME Funding. London: Palgrave MacMillan. https://doi.org/10.1057/978-1-137-58608-7_2
Rae, D. (2005). Entrepreneurial learning: a narrative-based conceptual model. Journal of Small Business and Enterprise Development, 12(3), 323-335. https://doi.org/10.1108/14626000510612259

Repečkienè, A., Kvedaraitè, N., Žvirelienè, R., \& Glinskiene, R. (2012). Measures facilitating reduction of academic youth unemployment and transfer from educational institutions to labour market (Lithuanian case). Economics and Management, 17(4), 1397-1409. https://doi.org/10.5755/j01.em.17.4.3006

Sardeshmukh, S., \& Corbett, A. (2011). The duality of internal and external development of successors: Opportunity recognition in family firms. Family Business Review, 24(2), 111-125. https://doi.org/10.1177/0894486510391783

Shane, S. (2009). Why encouraging more people to become entrepreneurs is bad public policy. Small Business Economics, 33(2), 141-149. https://doi.org/10.1007/s11187-009-9215-5

Tavistock Institute of Human Relations. (2002). Review of current pedagogic research and practice in the fields of post-compulsory education and lifelong learning. Final report, revised.

Varamäki, E., Tall, J., Viljamaa, A., \& Mäkelä, A. (2017). Unsuccessful SME business transfers. In N. Delener, \& C. Schweikert (Eds.), Changing business environment: Gamechangers, opportunities and risks (pp. 983-990). New York City: Global Business and Technology Association.

Williamson, N., Beadle, S., \& Charalambous, S. (2013). Enterprise education impact in higher education and further education: Final report. London: ICF GHK for Department for Business Innovation and Skills. 